UB ResearchOnline http://researchonline.ballarat.edu.au

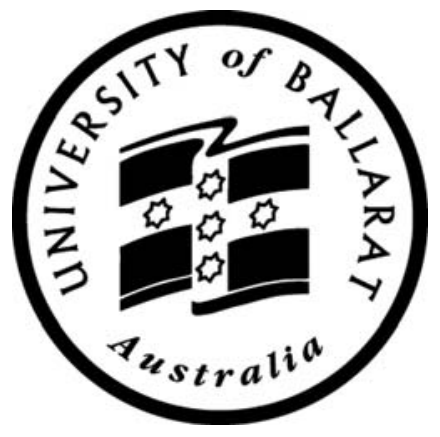

Reproduced here with the kind permission of the Author Jerry Courvisanos and the publisher Inderscience

Bibliographical info published as:

Courvisanos, Jerry. "A Post-Keynesian Innovation Policy for Sustainable Development." International Journal of Environment, Workplace and Employment 1, no. 2 (2005): 187-92.

Copyright (c) 2005 Inderscience

This is the publisher's version of the work. It is posted here with permission of the publisher for your personal use. No further distribution is permitted. 


\title{
A post-Keynesian innovation policy for sustainable development
}

\section{Jerry Courvisanos}

School of Business, University of Ballarat

P.O. Box 663, Ballarat, Victoria, 3353, Australia

E-mail: j.courvisanos@ballarat.edu.au

\begin{abstract}
Innovation and the environment are perceived as being in conflict within mainstream economics. Both are neglected themes in post-Keynesian economics, despite their prominence in general business discourse. A postKeynesian 'eco-sustainable framework' is specified, which can stimulate innovation with supportive public policy tools for the attainment of sustainable economic and ecological development. The framework aims at satisficing towards a 'sustainable society' based on the work of Michał Kalecki and Adolph Lowe. Kalecki argues for social control of investment, while Lowe argues for 'instrumental analysis' to public policy, linking human agency (imagination) to investment behaviour for the purpose of setting long-term goals. The goals are specified in terms of ecologically sustainable rules in the context of long-term carrying capacities of the ecosystem. Practical applications of this framework are also outlined.
\end{abstract}

Keywords: environment policy; ecological economics; innovation; investment planning; sustainable development; public policy framework; complexity systems.

Reference to this paper should be made as follows: Courvisanos, J. (2005) 'A post-Keynesian innovation policy for sustainable development', Int. J. Environment, Workplace and Employment, Vol. 1, No. 2, pp.187-202.

Biographical notes: Jerry Courvisanos is Deputy Director of the Centre for Regional Innovation and Competitiveness (CRIC) at the University of Ballarat in Victoria, Australia. He has been a consultant and adviser to local councils, regional development boards, and social service organisations, and an economics teacher for 25 years. His research interests include the economics of innovation and investment (i.e., the processes of innovation and how they affect investment spending, business cycles, and the long-term development of businesses and the economy), and Kaleckian and post-Keynesian economics.

\footnotetext{
"You've hit the (post-)Keynesians at a weak point; they and the supply siders seem like the last unreconstructed growth hounds around. Didn't Joan Robinson say something like, for all their talk of investment, the Keynesians have never asked investment in what?" (Doug Henwood, email comm., pkt net, 30 August 1997)
} 


\section{Introduction: investment and systemic failure}

A growing economy requires investment in the future. Economics defines fixed capital investment as planned expenditure on plant and equipment (or Means Of Production, MOP) that furnishes the productive processes for future goods and services. In a capitalist economy this role is centrally located in the private market sector. Unless specified otherwise, the term 'investment' in this paper refers to private business fixed capital investment [1].

Investment needs to be greater than the rate of depreciation of 'old' MOP in order for a capitalist economy to grow. The standard 'economics problem' arises with the need for investment at high and stable levels to produce economic growth. This will deliver both private profit growth (microeconomic objective) and long-term secure employment (macroeconomic objective). Economics research has identified technological innovation as the factor initiating strong investment. The 'technology problem' arises with the need for firms to find ways to harness such innovation that provides stable growth in profits and employment [2].

Two forms of systemic failure have been identified in the attempted resolution of both the economics and technology problems. The first is instability of investment, exemplified by the increasingly volatile investment cycles exhibited in capitalist economies as the process of market deregulation has been extended over the last 15 years. The increasing degree of market and technical uncertainty has generated these volatile investment cycles that result in cumulative boom in expansion and with it overcapacity. This is followed by strong sharp contractions in which there is a shift to speculative activities and debt-deflation [3-5; 6,pp.190-214].

The second is ecologically unsustainable investment which produces MOP that are inappropriate in terms of scale, location, and time, clearly identified most persuasively by Schumacher [7]. The aggregate impact of investment and the embodied technological solutions have been in the direction of decreasing ecological sustainability [8]. This has been occurring despite growing support for market-based environmental solutions in the 1980s and 1990s [9-10]. The scale of investment (large sized with strong technological input), its location (with emphasis on industrial clusters), and its cumulative impact through time all point to systemic failure of private investment decision making in delivering an innovative capital goods structure that leads to a more sustainable ecological environment. From an ecological standpoint, significant structural adjustments to the current operation of the private investment climate are required.

Both systemic failures point to the need to develop an investment strategy that addresses them conjointly. The next section argues that a post-Keynesian approach to this investment strategy is required due the limitations of the two extant approaches to sustainable development. The neoclassical substitution approach of environmental economics is unable to address the dual systemic failure, except on the basis of reducing conflicts to optimal cost-benefit algorithms. The ecological economics approach eschews the neoclassical resolution but is unable to handle the instability of investment that leads to market and technical uncertainty, rendering the optimal (or maximum) ecological scale of resource use impossible to implement.

An 'eco-sustainable framework' for developing a post-Keynesian innovation policy is set out in Section 3 of the paper. The framework aims to provide a process by which to stimulate innovation with supportive public policy tools for the attainment of sustainable economic and ecological development. Harnessing innovation for sustainable 
development is the overriding principle. The perspective is based on satisficing behaviour given endogenous private firm constraints created by the two systemic failures. These failures force private agents (i.e., managers) to operate within procedural rationality rather than optimal rationality. A new investment paradigm is encouraged that is both innovation-oriented and ecologically sustainable, such that the dilemma of sustainable economic growth and sustainable ecological diversity dissolves into a positive programme of cumulative causation.

The final substantive section of this paper outlines practical application of this framework using concrete examples of ecological-based strategies and their integration into a complete innovation policy with a significant public and private investment strategy. A link is then clearly established from the traditional Keynesian investment planning approach to the emerging goal-oriented and strategic environmental approaches implicit in the Montreal and Kyoto Protocols.

\section{A question of methodology}

Robert Heilbroner warned about 'Ecological Armageddon' in a widely reprinted 1970 article [11], yet more than 30 years later Davies [12] notes the alarm throughout the scientific and intellectual communities of humanity's lack of recognition of its situation. Davies writes that: "Whereas a few decades ago the number of warning voices was few, there is now a growing chorus, and prominent, respected professional groups and organisations have been adding their authority to the call for new policies" [12,p.257]. One crucial policy required in this ecological perspective is a public investment strategy with technological progress that allows entrepreneurial innovation that is ecologically sensitive. Consistent with the objective of overcoming the two systemic failures described above, a post-Keynesian methodology for such an innovation policy is required.

Interaction between the two systemic failures raises serious questions of the neoclassical market internalisation approach to environmental social costs, whether in the welfare (cost-benefit) or free market versions. Unstable and ecologically unsustainable path-dependent investment leads to volatile market signals creating conditions for technical uncertainty in expectations about the future that results in cumulative short-run instability and cumulative long-run systems failure. The work by Minsky [3] on financial instability and by Crotty [5] on growth-safety trade off in capital goods investment, show the cumulative volatility arising from market signals to investment (both financial and physical). Recent work on technology embodied in investment has shown the rise of severe cyclical activity whenever new technological systems predominate, whether it is the steam engine or electronic information technology [13]. Then, in the long run when technology becomes embedded, past technology decisions shape future investment decisions and myopic selection pressures operate against the automatic price response mechanism providing the appropriate ecologically sustainable technology coming forth [14,pp.372-379].

The new neoclassical growth models support the position in this paper of two forms of systemic failure arising out of the economics and technology problems. Economic instability implies cyclical swings in output that increases market uncertainty leading to delays or suspension of investment and Research and Development (R\&D) in new 
technologies [15,p.269]. This can increase environmental degradation even in a zero economic growth scenario [16]. From the ecological perspective, this problem implies additional environmental spillover costs for economic agents due to investment in unsustainable technologies. Benhaïm and Schembri [17,p.131] explain that neoclassical optimality prevents new growth models from providing any guidance for public or private investment strategies despite acknowledging systemic failures. The equilibriumoptimality constructions cannot perceive sustainable development 'other than a state to reach' within very restrictive settings. Evolution of the system through technical change in historical time is not possible under optimality conditions. This neglects the important phases in business cycles and economic development for which different technological trajectories and associated dynamics need to be observed [18]. The neoclassical methodology is found wanting.

An alternative methodology to the neoclassical position is required with the ability to develop investment strategies that create a predictable but strategic focus that induces innovation that is cumulatively changing towards an ecologically sustainable investment programme. Consideration should be given to the large literature developed by ecological economists [19]. Forstater [20,pp.17-18] explains that ecological economics has taken a pluralistic approach to methodological issues, but with common themes centred on pre-analytical vision and imagination, structural analysis, scenario storylines, and adaptive implementation paths. Forstater goes on to show that these themes effectively reject the neoclassical hypothetico-deductive method together with the positive/normative dichotomy, but are consistent with Adolph Lowe's 'Instrumental Analysis'. The most significant commonality between the two is the policy perspective of working backwards "from the vision of the desired ends to find sustainable paths for its attainment" [20,p.16].

When it comes to developing a framework for policy, Forstater argues that ecological economists have left this area "underdeveloped" [20,p.20]. This has left ecological economists with a policy framework that consists of an extension of neoclassical economics tools grafted onto a heterodox methodological perspective. Essentially it is 'constrained market environmentalism' where the investment process operates in the same way as with neoclassical economics but with the crucial pre-analytic setting of an optimal (or maximum) scale of production [21,pp.36-49]. Size of the investment projects is predetermined, yet there exists market-based encouragement to develop ecologically sustainable technology. Investment instability will still create the same endogenous uncertainty problems that are identified with neoclassical economics. Michal Kalecki's 'perspective planning' can provide a more effective strategic innovation and investment policy framework that ameliorates uncertainty, but with a historically evolving approach that is consistent with the ecological economics methodology themes outlined above.

The drive to develop a framework for innovation policy in this paper is governed by an ecologically sustainable pre-analytic vision consistent with the ecological economics position. Using Lowe's 'instrumental analysis' and working backwards from a sustainable development vision of innovation, a demand-oriented public investment strategy can be developed that has a post-Keynesian methodology derived from the work of Kalecki. A framework that builds on this approach is presented in the next section.

The final element in this framework is a complexity analysis ensuring a business environment that is constantly changing with incentives to innovate and specialise [12,p.216]. A business ecology that is continuously developing and unfolding as a complex system allows innovation to become embedded and intrinsic as the driver of the economic system as identified by Adam Smith in his Wealth of Nations. This business 
ecology needs to be congruent with the environmental ecology, something that the noncomplexity neoclassical economics cannot aspire to achieve.

Complexity as a concept recognises an open system which overall ('macroscopically') creates and dissolves patterns over time, whereas the neoclassical approach involves reducing a closed system into its individual parts. The science of complexity allows investigation of open systems in which "the collective behaviour of many basic but interacting units evolves over time, with self-organisation and adaptation" [22,p.7]. This fits into the evolutionary and cumulative causation aspects of the investment cycle. As such the framework developed here is situated in the integration of post-Keynesian and evolutionary models of complexity outlined by Rosser [23] and used to understand Twentieth Century capitalist development by Cornwall and Cornwall [24].

\section{The eco-sustainable framework}

This section introduces a set of economic analytics that are aimed to operate in a world of complexity with fundamental uncertainty and cumulative change within a framework of an innovative and sustainable environment. These analytics have at their base satisficing rather than optimising objectives in terms of policy actions. The efficiency and ethical reasons for public intervention towards sustainable development when there is fundamental (or 'hard') uncertainty, irreversible processes and strategic learning has been logically argued by Vercelli [25]. He concludes with the need for a procedural 'designing rationality' that is "aimed at designing a project of harmonious interaction between economic development and the natural environment and able to specify a strategy for its implementation" [25,p.273]. The eco-sustainable framework below is a concrete step towards such a policy intervention system.

An economic framework is needed that is broadly rational in rigorous economic terms and also ecologically sustainable in handling ecosystem dilemmas. This eco-sustainable framework begins with an identifiable goal and then develops a strategy of public intervention in order to implement the goal. The goal is the policy perspective definition of sustainable development adopted by Vercelli [25,p.268]: "development could be considered sustainable only when generations are guaranteed a set of options at least as wide as that possessed by the current generation".

The framework outlined is based on two analyses. First is Adolph Lowe's 'instrumental analysis' as a way of using 'instruments' to achieve agreed goals. Lowe [26] established an analytical framework designed to enable rules of formal logic to be applied to economic cause-and-effect sequences over historical time. This framework is particularly aimed at using such cause-effect principles to set up state structural adjustment policies that can deliver a sustainable, equitable, and ecologically supportive economic environment. This eco-environment is the stipulated end. To Lowe [26,pp.11-12] it involves 'the search for the economic means suitable for the attainment of any stipulated end'. To this procedure I have assigned the label of "instrumental analysis" [27].

Lowe's ecological concern is clearly evident from early on in his writings and then later makes an explicit attempt "to incorporate environmental factors into his analysis" [20,pp.7-11]. The position taken by Lowe in these later works is to argue that industrial progress and the new technological revolution cannot continue to deliver the economic 
growth rates that governments desire and corporations strategise over in advanced capitalist economies. Only solution put forward is the gradual redistribution of resources to less advanced economies with concomitant reduction in required growth rates in more advanced economies [28]. This is a long-term solution that needs to be supported by strong political vision in advanced economies, but this is very difficult to generate. While politically advocating for this solution, economists can use Lowe's own instrumental analysis to assist achieving the same stipulated sustainable end by weaving a strategic innovation and investment policy regime that is strongly ecologically sensitive. Such a strategy could build on the recent political shift in advanced economies for public innovation policies that guide business towards stronger competitive advantage.

Public policy instrumental analysis needs to concentrate on investment, which is central to competitive advantage but also meets the Vercelli goal of sustainable development. Analysis and evidence show that uncertainty by the "mistake-ridden private sector' causes investment instability, thus undermining economic activity and competitive advantage [6,pp.190-192,29]. Private corporate investment strategy that is best suited to innovation needs a secure business environment, but one which has public policies that support continuous development and change [30]. This situation potentially offers post-Keynesians the opportunity to influence innovation in an ecologically sustainable direction. In market-based economic regions or nations that lack relevant supportive physical and social infrastructure, there is insufficient order and coherence to impel the creation of innovative ecologically sustainable investment projects by the private sector without a state structural adjustment policy.

Second is Michal Kalecki's 'perspective planning' [31]. This is incorporated into the framework to provide an investment strategy to establish motivation and voluntary conformity towards ecologically appropriate goals. A path of dynamic diffusion of new technology systems, which is conducive towards innovation for a sustainable physical environment, needs to be established. This requires long-term investment strategies to have an incrementally adjusting perspective planning approach [32]. To achieve this it is necessary to establish specific practical short-term goals to induce innovation in investment that eventually adds up to the long-term goals specified. The plan must be continually assessed at every short-term end-point to see whether it is necessary to revise the goals and the strategy for reaching the broad-based long-term scenario. A perspective plan with these goals is set up to form a specific investment programme in consort with agreed ecological 'rules' that deliver the type of ecological sustainability determined by the 'instrumental analysis'.

In Kalecki's planning approach, there are two specific resource-saving parameters that provide ecological-efficient criteria to rules formulation. One is the coefficient of real depreciation, the aim of which is to reduce this coefficient by proper maintenance and repair systems to equipment and infrastructures. The other is the coefficient of better utilisation of existing productive capacity. "Greater output may be obtained from existing plant due to improvements in the organisation of labour, more economical use of raw materials, elimination of faculty products, etc." [33,p.16], thus reducing the coefficient's value. Together these resource-saving coefficients provide a sound basis for ecological rules in a sustainable, but constrained, investment strategy.

Barbier [34] developed some ecologically sustainable rules that could form the basis of any Lowe-Kalecki planning approach. These rules deal with rates of both exploitation of natural resources and generation of wastes that specific ecosystems can assimilate for long-term 'carrying capacity' sustainability. The problem is that different 'stakeholders' 
(or interest groups) in the economy use alternative critical load carrying capacity measures in relation to the ecosystem. Within the context of tourism, Hoffmann [35] identifies three carrying capacity measures that can be applied to the ecosystem in general:

(1) physical capacity as the absolute limit that a resource can cope with

(2) ecological or real carrying capacity as the level beyond which there are unacceptable ecological impacts for ecologists

(3) social or effective carrying capacity as the level beyond which unacceptable change occurs in the production of the good or service in terms of overcrowding and altering social behaviour.

Large business interests tend to support (1), while small and local based businesses, public environmental bureaucracies, and ecologists tend to support (2). The direct service providers 'on the ground' (e.g., national park rangers, local environment groups, low-impact ecosystem-based services) tend to support (3). Kalecki's resource-saving coefficients can be applied to all three capacity measures.

The perspective planning approach needs to first set up a dialogue between all stakeholders on how to achieve a deeper ecosystem-sensitive market in any region or country using structural adjustment policies that plan to alter the economic base of that area. The aim is investment, not in 'end-of-pipe' solutions to the ecosystem, but in an innovative proactive strategy that significantly alters the operation of the economy using all the tools available in the new Information and Communication Technologies (ICT). This requires understanding of the possible means to develop the economy with ICT investment and an appreciation of the value of all three carrying capacity indicators as rules for monitoring, evaluating, and developing each stage in the plan. Networking between all the stakeholders over the goals, means, and their assessment must be rapid and continuous. Then processes need to be arranged where constructive dialogue concentrates on the means of achieving the goals based on the data available and rules used to assess this data. Once an investment plan has been developed, there must be continual reevaluation of these rules over time so that they are not static, but instead reflect the latest innovative technological changes. This enables the constrained investment strategy to be flexible and adaptable.

Economists currently writing on ecology and environment recognise that all attempts to incorporate ecological concerns, whether by the market or through planning processes, depend on the precautionary principle. Hodge [36,p.56] explains that to have confidence in the effectiveness of ecological rules, "any prescriptions will have to embrace a wide range of capital assets and precautionary rather than optimising approaches have to be adopted". The planning system behind these rules provide a level of precautionary confidence that induces innovation in investment that leads to revisions both in carrying capacities and economic growth rates for future iterative reevaluations of the perspective plan. This is a complexity-type cumulative and feedback process that has the ability to establish precautionary rules to meet the goal of sustaining the ecosystem, while regularly evaluating and revising the rules for getting there. Market signals and even optimal cost-benefit analysis beloved by neoclassical economists cannot provide such satisficing and precautionary guiding principles. 
Since it is impossible to define with any certainty what sustainability requires, a risk-averse investment strategy needs to be initially introduced, and not based on a static optimising (and optimistic) cost-benefit comparison. This points to the use of the effective carrying capacity rate as the critical ruling measure. Over time what sustainability requires is a 'shifting target' that depends on the new information and technology that becomes available and on the changing attitudes and expectations adopted by the generation that has democratic public control [36,p.56]. This democratic control implies grassroots input from the people who understand and operate within the fragile ecosystem together with ability to influence directly the goals and means used to develop the ecologically sensitive economy.

In achieving the sustainability objective, Hoffmann [35] argues for strategic alliances between the stakeholders. There are vast ideological and business differences between all the stakeholders, especially with regard to their support for different carrying capacity rules. Under these conditions, it seems alliance across all stakeholders will be very tenuous, if not impossible. Democratic control requires networking across all parties with specific details of the stipulated sustainable end, but then decisions on the plans and implementation must be arrived at by majority support. The minority, even if more economically powerful, must accept the need to act within the bounds of the majority-based plan and policies.

Borrowing from the 'cumulative causation' literature [37], the Lowe-Kalecki ecological framework provides a growth of effective demand based on certain sustainability rules that establishes certainty within which innovative investment can flourish. Continual iterative reevaluation of the investment plan encourages further innovation that leads to more acceptable and internationally competitive sustainability rules. This creates 'self-reinforcing internal dynamics' that induce strong international competitiveness with sustainable development that delivers full employment [38].

In summary, this framework has three crucial elements, with post-Keynesian principles in brackets:

1 Ecological rules that ensure capital investment is resource-saving with long-term carrying capacities which are sustainable ( $\mathrm{PK}$ - conventions with fundamental uncertainty).

2 Perspective, flexible, and risk-averse investment strategy with democratic control (PK - investment management and stability).

3 Cumulative effective demand that establishes a strong market share for environmental-based goods and services ( $\mathrm{PK}$ - demand-oriented stimulation).

\section{Practical application}

The eco-sustainable policy framework can be applied to the ecological sustainability question on the basis of recent work on sustainability rules. Three recent studies provide practical supportive implementation strategies for the type of framework proposed here. One is from a strategic business management perspective. The second is from a national public environmental policy perspective. The third is from an evolutionary perspective and its application to the specific area of transport with transition to sustainable mobility. All three are practical innovation strategies that do not address the investment issue. This section outlines how such diverse practical strategies can be incorporated into a 
post-Keynesian innovation and investment policy. It is an approach based on dynamic satisficing objectives towards a stipulated sustainable goal, and it aims to encourage cumulative causation so that ecologically supportive innovation is enhanced over time.

Porter and van der Linde [39] explore the central strategic management role of innovation by private firms in ending the stalemate between stricter environmental regulations (or rules) and attempts by business to roll back these rules seen as costly and anticompetitive. The authors reject neoclassical optimisation implied in this 'static view of environmental regulation'. Firms operate in a dynamic competitive situation; constantly finding solutions to problems makes these firms more competitive. "Properly designed environmental standards can trigger innovations that lower the total cost of a product or improve its value" [39,p.120]. With incomplete information and limited time and attention by managers to assess the complex new world of environmental issues, rules set up by public policy makers offer a procedural rationality construct. From this construct firms can make satisficing environmentally supportive innovative decisions in the current transitional phase of the economy, as it moves into the post-industrial digital economy. In this new world, "Static thinking causes companies to fight environmental standards that actually could enhance their competitiveness" [39,p.128].

Using case study examples of many companies, Porter and van der Linde [39] show that good regulation can enhance risk-taking and experimentation within a predictable business and ecology setting. Where this has been successful it has been due to good regulation [40]. Such good regulation is clear and stable in its direction, while creating maximum opportunity for firms to solve innovatively the problems that rules create. Good rules do not lock firms into particular technology and are gradually improved in line with private sector technological developments. All this requires a sustainable investment planning process with technical change; otherwise risk and experimentation will not flow through into adequate production runs.

Wallace [41] develops the same theme as Porter and van der Linde, this time from the perspective of an environmental public policy maker. Wallace, in his book, details many examples of countries that have implemented 'good regulation'. It is possible for policy makers to create opportunities and incentives for firms to be innovative for a sustainable ecological environment. However, innovation requires strategic investment planning with coordination by private and public organisations. To do this well, public policy makers "need to understand the nature of decision making in industry; how it is conditioned by perceptions of markets and risk, existing technological capacities and constraints and the capacity for change" [41,p.22]. Six national studies and two industry case studies by Wallace show that this can be done.

All the Wallace [41] studies show that successful innovation requires a secure corporate environment, but with the nature of corporate systemic instability, public control is required. Further, the studies show that clear public policy ecological directions and rules that allow for adaptation and incremental change bring forth the required corporate innovation that supports creatively the ecosystem, rather than prescriptive static regulations that result in 'head-in-the-sand' responses that favour costly 'end-of-pipe' technological solutions [41,p.17]. Nations need to set a coherent, comprehensive agenda for the environment that encourages flexible and innovative responses from the private sector. Wallace identifies The Netherlands as having taken this process the farthest, but there are fears from other nations of the costs of competitive disadvantage measured in current static neoclassical economic terms [42]. 
Kemp et al. [43] outline public and private sector processes in the coevolution of technologies and industry structures towards sustainable development through the identification of ecologically sound niche markets that are already attractive to users. Here 'Strategic Niche Management' (SNM) can be applied. This is a process where experiencing learning-by-doing through these niches informs technical improvement and supports public and private iterative planning with the aim to expand the niche and at the same time encourage institutional embeddedness. The niche space is protected temporarily from the full force of normal selection pressures, which allows a testbed to incubate the new technology within a domain of genuine effective demand.

SNM is especially suited for promoting sustainable transport, where barriers to ecological sustainability are strong and yet where potential for new forms of sustainable mobility are evident in niche markets throughout advanced and Third World economies. Kemp et al. [43] provide three examples of SNM in Europe: lightweight electric vehicles in Mendrisio, organised car sharing in Switzerland, and rolling highways in Sweden. What is crucial for the investment planning perspective is the need of up-front investment in new infrastructure, production outlays and maintenance systems' where there is strong attachment to existing modes of mobility and coordinating actors actions are difficult [43,pp.2-3]. Thus, an innovative investment strategy in concert with SNM can provide a clear realistic path towards technological succession as identified by [44] in simulation modelling exercises.

The eco-sustainable framework provides a comprehensive approach to how an investment strategy can be introduced into an economy in order to derive the stipulated goal of an innovative, competitive and ecologically sustainable environment. Currently only The Netherlands has been prepared to go down this path significantly, with many of the elements of the Lowe-Kalecki framework in its public programme, such as: national strategic environment plan, short-term targets and target groups, private sector cooperation, voluntary conformity, citizens' group input. This is backed by the threat of regulation and withdrawal of support policies like subsidies [41,pp.43-61]. Crucially missing from The Netherlands plan is the ability to promote innovation through technological succession, which is where investment planning in concert with SNM can provide the necessary link to new sustainable technologies.

Figure 1 summarises the argument of this paper in the grid and provides a flowchart of the investment planning process on the bottom. The left column has the three pillars of the eco-sustainable planning framework. The centre column sets out the criteria for sustainable development required in both public and private sector investment planning within specific institutional and cultural domains. The right column shows how specific implementation strategies for innovation, outlined above, support the investment plan. The bottom row is a flowchart which indicates how one column should interact with the next in the planning process. The flowchart is a practical procedure for a coherent planning process. Each of the supporting strategies is currently in operation as separate entities in different places. What distinguishes this study is the appropriation of these actual strategies into a cohesive post-Keynesian planning framework for investment that allows these strategies to induce technological innovation for sustainable development. This then takes the strategies out of the environmental divisions of the public/private sectors and locates them in their central planning processes. Then, the environment is no longer a separate strategy, but instead a stipulated end that is integrated in the strategic management and planning of any (and every) organisation. 
Figure 1 Summary of the Lowe-Kalecki sustainable development process

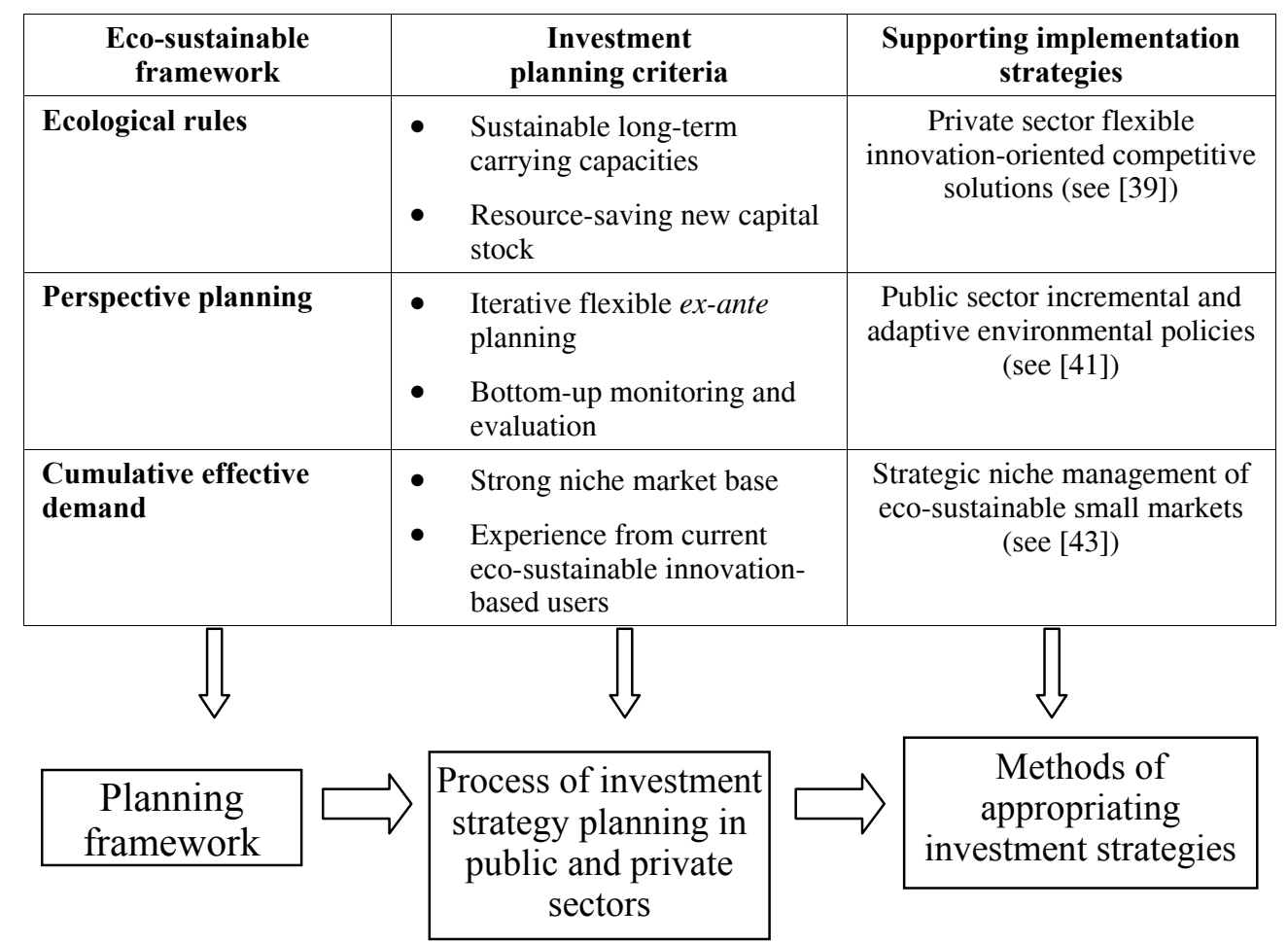

The process outlined in Figure 1 is a practical application of the eco-sustainable framework at both the technical and political levels. At the technical level, Rip and Kemp [14,pp.357-64] explain how coevolution can be sustained by the use of design hierarchies, mapping techniques, and public sector innovation programmes. All three are at a highly technocratic level, but essential to bring forward radical innovations within an appropriate industrial structure that can survive the infant stage. The sustainable development process outlined above enables these technical processes to be seen as central for future economic development.

At the political level, perspective planning requires the twin processes of monitoring and evaluation to incrementally adjust the short-term end-points while revising the long-term goals and scenarios. This is done at the grassroots of the organisation in order to sustain voluntary conformity to the broad plan objectives. The perspective plan approach as outlined in Kalecki [31] allows democratic control of the technocratic process of shifting to an ecologically sustainable path, whether this control is by private firm stakeholders, regional communities, national constituencies, or representatives of global institutions (i.e., ILO, WTO, IMF). Once the voluntary conformity requirement is agreed to, the investment strategy is constrained according to ecological rules. The process of innovation and change can be managed in this dynamically flexible manner, allowing the investment constraints to be adapted over time [45]. 
For research, the Lowe-Kalecki framework provides a useful analytical device to assess a nation, region, industry sector, or international organisational structure in relation to sustainable development. The strategic planning and implementation processes can be assessed in terms of fitting into the eco-sustainable framework. The closer the policies and actions of agents come to meeting the conditions set out in this framework, the more effective are these actions in attaining the long-term sustainable objectives. It should be clear that the framework is aimed at assessing the 'instrumental stage' of actions and not any final outcome. There is no optimal end-point. Instead, there is a stipulated sustainable development goal that the innovation policy framework outlined above allows continued evolution to a more ecologically sensitive society.

\section{Conclusion}

Dominance in economics of the neoclassical 'optimal' rationalist approach needs to be replaced by an eco-sustainable 'satisficing' approach. As such, the neoclassical substitution to optimality is then converted into an analysis of the structural composition of sustainable output. This can only succeed if the specifics of an eco-sustainable position can be clearly enunciated and its vision seen to be practically achievable.

The aim of this paper has been to spell out in some detail an eco-sustainable innovation policy for both the private and public sectors working within an overall investment planning strategy that has as its major criteria, sustainable ecological rules (or conventions), perspective planning, and cumulative effective demand. These three investment criteria are based on major post-Keynesian principles. This then addresses the Joan Robinson query of 'investment in what?' from an ecological perspective.

Using the insights of Adolph Lowe and Michal Kalecki into investment paths, together with their nascent ecological concerns, an eco-sustainable framework is presented. This framework aims to engender innovative technological solutions that are ecologically sensitive. Concrete application with flexible and adaptive implementation strategies that already operate $a d$ hoc in market economies is the basis for this outcome. The framework allows for an integration of an ecological-based investment planning criteria with supportive implementation strategies to deliver an effective technological innovation policy for sustainable development.

Central to this post-Keynesian innovation policy framework is a theory of production that views capital investment as a process of the capitalist economy and does not consider capital stock as a natural endowment. Such a perspective provides strong basis for integrating ecologically sustainable development principles with post-Keynesian economics.

\section{Acknowledgment}

The author thanks the following for advice and help on previous versions of this paper: Dallas Hanson, Peter Hay, René Kemp, David P. Levine, Tracy Mott, Allen Oakley. The author is alone responsible for the views and any errors in this paper. Paper presented at the Eighth International post-Keynesian Workshop as part of the panel session on post-Keynesian Environment Policy, 27-29 June, 2004 at the University of Missouri, Kansas City, USA. 


\section{References and Notes}

1 For a critical exposition of mainstream neoclassical investment theory and an outline of the alternative post-Keynesian investment analyses, see Baddeley, M. (2003) Investment Theories and Analysis, Basingstoke, UK and New York, USA: Palgrave Macmillan.

2 Two different theoretical perspectives in Kalecki [46] and Solow [47] specify the important role of technological innovation for investment and growth. Denison [48] provided the first detailed empirical support. More recent studies by Sahal [49], Nelson [50], Gomulka [51], Verspagen [52], Fagerberg [53], and von Tunzelmann [54] provide accounts of how this technology problem has been addressed in capitalist economies.

3 Minsky, H.P. (1982) 'Can “It” happen again?', Armonk, N.Y.: M.E. Sharpe.

4 Freeman, C. and Perez, C. (1988) 'Structural crises of adjustment, business cycles and investment behaviour', in G. Dosi, C. Freeman, R. Nelson, G. Silverberg and L. Soete (Eds.) Technical Change and Economic Theory, London: Pinter, pp.38-66.

5 Crotty, J.R. (1992) 'Neoclassical and Keynesian approaches to the theory of investment', Journal of Post Keynesian Economics, Summer, Vol. 14, No. 4, pp.519-542.

6 Courvisanos, J. (1996) Investment Cycles in Capitalist Economies: A Kaleckian Behavioural Contribution, Cheltenham: Edward Elgar.

7 Schumacher, E.F. (1974) Small is Beautiful: A Study of Economics as if People Mattered, London: Abacus/Sphere Books, (originally published in 1973 by Blond \& Briggs).

8 Meadows, D.H., Meadows, D.L. and Randers, J. (1992) Beyond the Limits: Confronting Global Collapse, Envisioning a Sustainable Future, White River Junction VT: Chelsea Green Publishing.

9 Kinrade, P. (1995) 'Towards ecologically sustainable development: the role and shortcomings of markets', in R. Eckersley (Ed.) Markets, The State and The Environment: Towards Integration, South Melbourne: Macmillan, pp.86-109.

10 Dosi, C. and Moretto, M. (1997) 'Pollution accumulation and firm incentives to accelerate technological change under uncertain private benefits', Environmental and Resource Economics, Vol. 10, pp.285-300.

11 Heilbroner, R. (1970) 'Ecological armageddon', R. Heilbroner (Ed.) Between Capitalism and Socialism: Essays in Political Economics, New York: Random House.

12 Davies, G. (2004) Economia, Sydney: ABC Books.

13 Courvisanos [6] has combined the Minsky and Crotty analyses to develop a 'susceptibility cycle' of investment at the agency behavioural level involving technological innovation. Case study patterns provide support to this concept of cumulative instability. See also Freeman and Perez [4].

14 Rip, A. and Kemp, R. (1998) 'Technological change', in S. Rayner and E.L. Malone (Eds.) Human Choice and Climate Change, Volume 2: Resources and Technology, Columbus: Battelle Press, pp.327-399.

15 Aghion, P. and Howitt, P. (1998) Endogenous Growth Theory, Cambridge, Mass.: The MIT Press.

16 Byrne, M.M. (1997) 'Is growth a dirty word? Pollution, abatement, and endogenous growth', Journal of Development Economics, Vol. 54, pp.261-284.

17 Benhaïm, J. and Schembri, P. (1996) 'Technical change: an essential variable in the choice of a sustainable development trajectory', in S. Faucheux, D. Pearce and J. Proops (Eds.) Models of Sustainable Development, Aldershot: Edward Elgar.

18 As was noted by Aghion and Howitt about endogenous growth, 'the economy is always a scaled down version of what it was years ago'. [17,pp.131-132]

19 Ecological economics as a school of thought has as its major journal, Ecological Economics. From a European perspective see the International Journal of Sustainable Development. Some representatives of ecological economics in the bibliography are [55-59]. 
20 Forstater, M. (2004) 'Visions and scenarios: Heilbroner's worldly philosophy, Lowe's political economics, and the methodology of ecological economics', Ecological Economics, forthcoming. Page references refer to mimeo copy.

21 Van den Bergh, J. (1996) Ecological Economics and Sustainable Development, Cheltenham: Edward Elgar.

22 Coveney, P. and Highfield, R. (1995) Frontiers of Complexity: The Search for Order in a Chaotic World, New York: Fawcett Columbine.

23 Barkley, Jr., R.J. (2004) 'Complex dynamics and post-Keynesian economics', Paper Presented at Conference on Complexity, Endogenous Money and Exogenous Interest Rates, Festschrift in Honour of Basil J. Moore, University of Stellenbosch, South Africa, January $7-11$.

24 Cornwall, J. and Cornwall, W. (2001) Capitalist Development in the Twentieth Century: An Evolutionary-Keynesian Analysis, Cambridge: Cambridge University Press.

25 Vercelli, A. (1998) 'Sustainable development, rationality and time', in S. Faucheux, D. Pearce and J. Proops (Eds.) Models of Sustainable Development, Aldershot: Edward Elgar, pp.259-276.

26 Lowe, A. (1976) The Path of Economic Growth, Cambridge: Cambridge University Press.

27 Working backwards from end to means is a search procedure referred to as retroduction and which Lowe uses to make 'regressive inferences'. For a detailed exposition, see [60]. For an overall perspective of Lowe's work, see [61].

28 Forstater [20,pp.9-11] quotes passages from Lowe's writings to this effect.

29 See also Richardson [62] for details on lack of coordination in markets for investment and the systemic failures that this creates. Richardson goes on to specify how investment coordination through information agreements and industrial concentration can assist in developing micro-goals in policy-oriented strategies.

30 Kay, J. (1993) Foundations of Corporate Success: How Business Strategies Add Value, Oxford: Oxford University Press.

31 Kalecki, M. (1986) Selected Essays on Economic Planning, Cambridge: Cambridge University Press.

32 Vercelli [25,p.274] in his conclusion explains why long-term goals need to be established: "One of the main reasons for the deterioration of environmental problems may be ascribed precisely to the myopia of economic agents increasingly obsessed by very short-run objectives. Short-run rationality produces a profound irrationality in the longer run. Only a broader long-run rationality may produce a process of sustainable development avoiding deep regrets."

33 Kalecki, M. (1993) Collected Works of Michal Kalecki, Volume IV: Socialism - Economic Growth and Efficiency of Investment, in J. Osiatyński (Ed.) Oxford: Clarendon Press.

34 Barbier, E. (1989) Economics, Natural-Resource Scarcity and Development, London: Earthscan Publications.

35 Hoffmann, H.B. (1998) 'The tourism industry and the evolving need for strategic alliances: a Doñana perspective', Paper Presented at the Seventh International Greening of Industry Network Conference, Rome, November.

36 Hodge, I. (1995) Environmental Economics: Individual Incentives and Public Choices, London: Macmillan.

37 Ricoy, C.J. (1987) 'Cumulative causation', in J. Eatwell, M. Milgate and P. Newman (Eds.) The New Palgrave: A Dictionary of Economics, London: Macmillan, Vol. 1, pp.730-735.

38 For detailed account of this framework with its origins, rigorous explanation and policy implications, see Courvisanos, J. (1998) 'Investment planning towards an innovative and sustainable environment', School of Economics Discussion Paper 98-02, University of Tasmania, Hobart. 
39 Porter, M.E. and van der Linde, C. (1995) 'Green and competitiveness: understanding the stalemate', Harvard Business Review, September-October, pp.120-134.

40 In another paper, Porter and van der Linde [63,p.110] rebut the arguments of neoclassical economists to their rules-based innovation thesis. Essentially, neoclassical economic models do not have explanatory power when it comes to the dynamics of innovation, especially in relation to environmental-based investment that represent a very small percentage of overall investment.

41 Wallace, D. (1995) Environmental Policy and Industrial Innovation: Strategies in Europe, The USA and Japan, London: The Royal Institute of International Affairs and Earthscan Publications.

42 The Australian Government is an example of this neoclassical 'optimisation' approach by rejecting strongly in Kyoto the imposition of the Rio greenhouse gas environment guidelines because it wants to protect the declining export coal industry and the perceived increased costs of regulation on other export industries (see Barratt, P. (1998) 'Implications of the Kyoto protocol for Australian government and policy makers', Greenhouse Beyond Kyoto: Issues, Opportunities and Challenges, proceedings from conference held in Canberra, Bureau of Rural Sciences, Commonwealth of Australia, AGPS, Canberra, March 31-April 1, 1998).

43 Kemp, R., Truffer, B. and Harms, S. (2000) 'Strategic niche management for sustainable mobility', in K. Rennings, O. Hohmeier and R.L. Ottinger (Eds.) Social Costs and Sustainable Mobility. Strategies and Experiences in Europe and the United States, Heidelberg:Physical Verlag, pp.167-187.

44 Windrum, P. and Birchenhall, C. (1998) 'Is life cycle theory a special case?: Dominant designs and the emergence of market niches through coevolutionary learning', Structural Change and Economic Dynamics, Vol. 9, pp.109-134.

45 Holt and Pressman [64,p.157] note: "Buchanan pointed out that most people are not like Keynes, and so we can not expect them to sublimate their own desires to national economic well-being." The perspective planning-voluntary conformity process, developed in this paper, is the response to Buchanan as to why politically the appropriate policies towards sustainable development can be employed in the face of self-interest that can destroy national interest.

46 Kalecki, M. (1954) Theory of Economic Dynamics, London: George Allen \& Unwin.

47 Solow, R.M. (1957) 'Technical change and the aggregate production function', Review of Economics and Statistics, August, Vol. 39, pp.312-320.

48 Denison, E. (1962) 'The sources of economic growth in the U.S.', Committee for Economic Development, New York.

49 Sahal, D. (1981) Patterns of Technological Innovation, Cambridge, Mass: Addison-Wesley.

50 Nelson, R. (1990) 'Capitalism as an engine of progress', Research Policy, June, Vol. 19, No. 3, pp.193-214.

51 Gomulka, S. (1990) The Theory of Technological Change and Economic Growth, London: Routledge.

52 Verspagen, B. (1993) Uneven Growth Between Interdependent Economies: An Evolutionary View of Technology Gaps, Trade and Growth, Aldershot: Edward Elgar.

53 Fagerberg, J. (1994) 'Technology and international differences in growth rates', The Journal of Economic Literature, Vol. XXXII, pp.432-457.

54 von Tunzelmann, G.N. (1995) Technology and Industrial Progress: The Foundations of Economic Growth, Aldershot: Edward Elgar.

55 Costanza, R. (1994) 'Three general policies to achieve sustainability', in A. Jansson, M. Hammer, C. Folke and R. Costanza (Eds.) Investing in Natural Capital: The Ecological Economics Approach to Sustainability, Washington D.C.: Island Press, pp.392-407.

56 Daly, H.E. (1996) Beyond Growth: The Economics of Sustainable Development, Boston: Beacon Press. 
57 Faber, M., Manstetten, R. and Proops, J. (1996) Ecological Economics: Concepts and Methods, Cheltenham: Edward Elgar.

58 Faucheux, S., Pearce, D. and Proops, J. (Eds.) (1996) Models of Sustainable Development, Aldershot: Edward Elgar.

59 Faucheux, S., O'Connor, M. and van der Straaten, J. (Eds.) (1998) Sustainable Development: Concepts, Rationalities and Strategies, Dordrecht: Kluwer Academic Publishers.

60 Forstater, M. (1999) 'Working backwards: instrumental analysis as a policy discovery procedure', Review of Political Economy, Vol. 11, No. 1, pp.5-18.

61 Oakley, A. (1987) 'Introduction: Adolph Lowe's contribution to the development of a political economics', in A. Lowe (Ed.) Essays in Political Economics: Public Control in a Democratic Society, New York: New York University Press.

62 Richardson, G.B. (1960) Information and Investment: A Study in the Working of the Competitive Economy, London: Oxford University Press.

63 Porter, M.E. and van der Linde, C. (1995) 'Toward a new conception of the environment-competitiveness relationship', Journal of Economic Perspectives, Fall, Vol. 9, No. 4, pp.97-118.

64 Holt, R. and Pressman, S. (1999) 'The dissent of economists: a response to Courvisanos and Jones', History of Economics Review, Summer, No. 30, pp.155-157. 